\title{
ANALISIS JALUR FAKTOR MAKROEKONOMI TERHADAP RETURN SAHAM SYARIAH ${ }^{1)}$
}

\author{
Ardina Talitha Nidya \\ Mahasiswa Program Studi S1 Ekonomi Islam-Fakultas Ekonomi dan Bisnis-Universitas Airlangga \\ Email: ardinatalitha@yahoo.co.id \\ Imron Mawardi \\ Departemen Ekonomi Syariah-Fakultas Ekonomi dan Bisnis-Universitas Airlangga \\ Email: ronmawardi@yahoo.co.id
}

\begin{abstract}
:
This research aims to determine the influence of macroeconomic factors on the profitability and stock return of PT. Bank Panin Dubai Syariah, Tbk period 2014-2017. The approach is a quantitative approach using path analysis. The exogenous variables that used are inflation, Gross Domestic Product (GDP), Bl rate, and exchange rate while the endogenous variable is stock return and the intervening variable is profitability. The result of this research indicates that inflation has no significant effect on profitability, GDP has no significant effect on profitability, BI rate influences positively significant on profitability, exchange rate influences negatively significant on profitability, inflation has no significant effect on stock return, GDP has no significant effect on stock return, BI rate has no significant effect on stock return, exchange rate influences negatively significant on stock return, and profitability has no significant effect on stock return of PT. Bank Panin Dubai Syariah, Tbk period 2014-2017.
\end{abstract}

Keywords: Macroeconomic, Profitability, Stock Return, Islamic Bank

\section{PENDAHULUAN}

Latar Belakang

Dewasa ini, banyak sarana investasi yang dapat dipilih untuk menempatkan dana yang dimiliki agar lebih produktif dan bermanfaat bagi orang lain. Sarana yang efektif sangat diperlukan dalam menanamkan modal yang dimiliki oleh investor sebagai wadah untuk menambah nilai kekayaan yang dimilikinya. Menurut Darmadji dan Fakhruddin (2006:1), "pasar modal merupakan sarana pendanaan bagi perusahaan maupun institusi lain (misalnya pemerintah) dan sarana bagi kegiatan berinvestasi". Hal ini terbukti dari banyaknya industri dan perusahaan yang telah memilih pasar modal sebagai sarana untuk mendapatkan pembiayaan usaha.

Sebagai negara dengan penduduk muslim terbesar di dunia, adalah suatu kewajaran jika tumbuh kecenderungan untuk menerapkan suatu sistem yang berlandaskan pada ajaran Islam, khususnya dalam hal perekonomian. Melihat pentingnya penerapan prinsip Islam dalam setiap aspek kehidupan masyarakat, pasar modal sebagai sarana dalam berinvestasi sudah selayaknya mampu menggabungkan prinsip Islam dalam setiap aktivitasnya. Kalangan pasar modal pun menyadari adanya potensi penghimpunan dana umat muslim.

Instrumen keuangan di pasar modal yang paling populer adalah saham. Menerbitkan saham sebagai bukti kepemilikan perusahaan merupakan salah satu pilihan perusahaan untuk meningkatkan aktivitas pendanaannya. Di sisi lain, saham juga lebih diminati oleh para investor karena saham mampu memberikan imbal hasil (return) yang lebih

1) Jurnal ini merupakan bagian dari skripsi yang ditulis oleh Ardina Talitha Nidya 041411431155

yang diuji pada 5 Januari 2018. 
Nidya, et al/Jurnal Ekonomi Syariah Teori dan Terapan Vol. 5 No. 10 Oktober 2018: 873-888; ANALISIS JALUR FAKTOR MAKROEKONOMI TERHADAP RETURN SAHAM SYARIAH

menarik dibandingkan dengan instrumen kevangan lainnya. Imbal hasil yang akan didapatkan oleh seorang investor apabila membeli suatu saham perusahaan adalah return yang terdiri dari dividen yield (bagian laba setelah pajak yang dibagikan) dan capital gain (kenaikan harga saham). Menurut fatwa DSN-MUI No.40/DSN-MUI/X/2003, saham syariah adalah suatu bukti kepemilikan atas suatu perusahaan yang memenuhi kriteria syariah dan tidak termasuk saham yang memiliki hak istimewa.

Faktor makroekonomi merupakan faktor yang dapat berpengaruh pada kinerja perusahaan dan tidak dapat dihindari oleh semua perusahaan. Menurut Tandelilin (2010:343), "variabel ekonomi makro yang perlu diperhatikan investor antara lain adalah tingkat suku bunga, tingkat inflasi, kurs rupiah, Produk Domestik Bruto (PDB), ....". Dalam penelitian ini digunakan faktor makroekonomi yang meliputi inflasi, PDB, BI rate, dan nilai tukar rupiah karena faktor tersebut sering digunakan dalam penelitian terdahulu yang membuktikan hubungan antara keempat faktor makroekonomi tersebut dengan return saham.

Kinerja perusahaan dapat dilihat dari besarnya profitabilitas yang diperoleh oleh suatu perusahaan. Rasio profitabilitas yang sering digunakan dalam menentukan kemampuan perusahaan memperoleh laba adalah Return on Asset (ROA). ROA memberikan suatu ukuran yang lebih baik atas profitabilitas perusahaan karena menunjukkan efektivitas manajemen dalam memanfaatkan penggunaan aktiva untuk memperoleh pendapatan.

PT. Bank Panin Dubai Syariah, Tbk merupakan satu-satunya Bank Umum Syariah (BUS) di Indonesia yang telah melakukan listing di BEl dan telah dinyatakan sebagai konstituen ISSI dimana saham bank syariah tersebut dapat dikatakan sebagai saham syariah yang tercatat dalam DES sejak tanggal 15 Januari 2014. Periode pengamatan dalam penelitian ini dipilih sebagaimana sesuai dengan periode perusahaan telah memperdagangkan sahamnya ke publik sejak terdaftarnya PT. Bank Panin Dubai Syariah, Tbk di Bursa Efek Indonesia secara resmi sebagai emiten syariah.

Didasarkan atas penjelasan mengenai saham syariah, faktor makroekonomi, profitabilitas, dan return saham, mendorong peneliti untuk memahami lebih lanjut mengenai faktor makroekonomi yang mempengaruhi profitabilitas dan return saham pada PT. Bank Panin Dubai Syariah, Tbk. Dari keterangan tersebut, peneliti tertarik melakukan penelitian dengan judul "PENGARUH FAKTOR MAKROEKONOMI TERHADAP PROFITABILITAS DAN RETURN SAHAM PADA PT. BANK PANIN DUBAI SYARIAH, TBK PERIODE 2014-2017".

\section{Rumusan Masalah}

Berdasarkan latar belakang yang diuraikan di atas, maka rumusan masalah yang diangkat dalam penelitian in adalah sebagai berikut: 
Nidya, et al/Jurnal Ekonomi Syariah Teori dan Terapan Vol. 5 No. 10 Oktober 2018: 873-888; ANALISIS JALUR FAKTOR MAKROEKONOMI TERHADAP RETURN SAHAM SYARIAH

1. Apakah faktor makroekonomi (inflasi, PDB, BI rate, dan nilai tukar rupiah) berpengaruh secara parsial terhadap profitabilitas pada PT. Bank Panin Dubai Syariah, Tbk periode 2014-2017?

2. Apakah profitabilitas berpengaruh secara parsial terhadap return saham pada PT. Bank Panin Dubai Syariah, Tbk periode 2014-2017?

3. Apakah faktor makroekonomi (inflasi, PDB, BI rate, dan nilai tukar rupiah) berpengaruh secara parsial terhadap return saham pada PT. Bank Panin Dubai Syariah, Tbk periode 2014-2017?

II. LANDASAN

TEORI

DAN

\section{PENGEMBANGAN HIPOTESIS}

Pada dasarnya, tujuan utama seorang investor menanamkan modalnya dalam bentuk investasi adalah mengharapkan keuntungan atau tingkat pengembalian (return) di masa yang akan datang. Return saham dapat dikatakan sebagai hasil yang diperoleh oleh investor atas investasi yang dilakukan pada masa lalu. Menurut Syarul (2000:1132), "return adalah pengembalian hasil atau laba atas surat berharga atau investasi modal, biasanya dinyatakan dalam suatu tingkat persentase".

Profitabilitas adalah kemampuan suatu perusahaan untuk menghasilkan laba atau profit. Menurut Kasmir (2016:196), hasil pengukuran rasio profitabilitas dapat dijadikan sebagai alat evaluasi kinerja manajemen, apakah telah bekerja secara efektif atau tidak. Salah satu ukuran profitabilitas yang sering digunakan dalam sebuah penelitian adalah Return on Asset
(ROA). Dendawijaya

(2009:199) menegaskan "Bank Indonesia sebagai pembina dan pengawas perbankan nasional menganjurkan profitabilitas bank diukur dengan menggunakan ROA karena lebih mengutamakan tingkat profitabilitas suatu bank diukur dengan menggunakan aset yang dananya sebagian besar dari dana simpanan masyarakat".

Apabila suatu negara mengalami perubahan kondisi makroekonomi baik positif maupun negatif, seorang investor akan mempertimbangkan hal tersebut dalam pengambilan keputusan investasi. Keputusan investasi yang akan diambil tentunya disesuaikan dengan kondisi ekonomi yang ada. Beberapa faktor makroekonomi sebagai representasi kondisi makroekonomi suatu negara adalah inflasi, Produk Domestik Bruto (PDB), Bl rate, dan nilai tukar rupiah.

Inflasi merupakan suatu fenomena ekonomi yang menarik untuk dibahas terutama oleh pemerintah berkaitan dengan dampaknya yang luas terhadap makro ekonomi agregat. Secara umum, inflasi adalah kenaikan tingkat harga secara agregat dari barang atau komoditas dan jasa selama suatu periode tertentu.

Menurut Sukirno (2006:34), Produk Domestik Bruto (PDB) dapat diartikan sebagai nilai barang-barang dan jasa-jasa yang diproduksikan di dalam negara tersebut dalam satu tahun tertentu. Dalam mengukur kesejahteraan perekonomian suatu negara, GDP Riil lebih baik 
Nidya, et al/Jurnal Ekonomi Syariah Teori dan Terapan Vol. 5 No. 10 Oktober 2018: 873-888; ANALISIS JALUR FAKTOR MAKROEKONOMI TERHADAP RETURN SAHAM SYARIAH

digunakan dibanding dengan GDP Nominal. Hal ini dilakukan karena GDP Riil tidak dipengaruhi oleh perubahan harga yang berlaku di pasar sehingga GDP Riil merupakan ukuran yang tepat dalam menilai kesejahteraan ekonomi terhadap pertumbuhan nilai barang dan jasa yang diproduksi oleh suatu negara dalam periode tertentu.

Dalam penelitian ini, Indeks Produksi Industri (IPI) digunakan sebagai representasi PDB karena tidak tersedianya data PDB bulanan. IPI merupakan indikator ekonomi yang mengukur nilai output produksi riil dengan tahun dasar tertentu sehingga perhitungannya tidak mengikutsertakan perubahan harga.

Dalam situs Bank Indonesia (BI, 2017), "BI rate merupakan suku bunga kebijakan yang menceminkan sikap kebijakan moneter yang ditetapkan oleh Bank Indonesia dan diumumkan kepada publik". Bl rate diumumkan oleh Dewan Gubernur Bank Indonesia setiap Rapat Dewan Gubernur (RDG) bulanan dan diimplementasikan pada operasi moneter yang dilakukan Bank Indonesia melalui pengelolaan likuiditas di pasar vang untuk mencapai sasara operasional kebijakan moneter.

Besarnya tingkat suku bunga yang ditetapkan oleh Bank Indonesia dapat dikatakan sebagai acuan bagi dunia perbankan dalam menentukan besarnya suku bunga yang ditawarkan pada masyarakat, meskipun dalam hal ini perbankan syariah tidak menggunakan suku bunga. Akan tetapi, bank syariah tidak akan dapat terlepas dari risiko tingkat bunga. Hal ini disebabkan karena pasar yang dijangkau oleh bank syariah tidak hanya untuk nasabah yang loyal terhadap bank syariah (Bambang, 2013:137 dalam Fatmawati, 2017:3).

Exchange rates (nilai tukar vang) adalah catatan harga pasar dari mata vang asing dalam harga mata vang domestik atau resiprokalnya, yaitu harga mata vang domestik dalam mata vang asing (Greenwald, 1982:430). Nilai tukar vang dapat menggambarkan tingkat harga pertukaran suatu mata uang terhadap mata vang lainnya dimana nilai tersebut dapat digunakan dalam aktivitas perekonomian seperti, investasi internasional dan transaksi perdagangan internasional.

Berdasarkan latar belakang, rumusan masalah, landasan teori, dan penelitian sebelumnya, maka dapat dirumuskan hipotesis penelitian sebagai berikut:

$\mathrm{H1}$ : Inflasi berpengaruh negatif signifikan terhadap Return on Asset (ROA) pada PT. Bank Panin Dubai Syariah, Tbk.

H2: Produk Domestik Bruto (PDB) berpengaruh positif signifikan terhadap Return on Asset (ROA) pada PT. Bank Panin Dubai Syariah, Tbk.

H3: $\mathrm{BI}$ rate berpengaruh negatif signifikan terhadap Return on Asset (ROA) pada PT. Bank Panin Dubai Syariah, Tbk.

H4: Nilai tukar rupiah berpengaruh negatif signifikan terhadap Return on Asset (ROA) pada PT. Bank Panin Dubai Syariah, Tbk. 
Nidya, et al/Jurnal Ekonomi Syariah Teori dan Terapan Vol. 5 No. 10 Oktober 2018: 873-888;

ANALISIS JALUR FAKTOR MAKROEKONOMI TERHADAP RETURN SAHAM SYARIAH

H5: Inflasi berpengaruh negatif signifikan terhadap return saham pada PT. Bank Panin Dubai Syariah, Tbk.

H6: Produk Domestik Bruto (PDB) berpengaruh positif signifikan terhadap return saham pada PT. Bank Panin Dubai Syariah, Tbk.

$\mathrm{H7}$ : $\mathrm{Bl}$ rate berpengaruh negatif signifikan terhadap return saham pada PT. Bank Panin Dubai Syariah, Tbk.

H8: Nilai tukar rupiah berpengaruh negatif signifikan terhadap return saham pada PT. Bank Panin Dubai Syariah, Tbk.

H9: Return on Asset (ROA) berpengaruh positif signifikan terhadap return saham pada PT. Bank Panin Dubai Syariah, Tbk.

Sesuai dengan tinjauan teoritis dan pengujian hipotesis di atas maka dapat dibuat persamaan struktural sebagai berikut:

$\mathrm{Y}_{1}=\beta_{1} \mathrm{INF}+\beta_{2} \mathrm{PDB}+\beta_{3} \mathrm{BIR}+\beta_{4} \mathrm{NTR}+\varepsilon_{1}$

$\mathrm{Y}_{2}=\beta_{5} \mathrm{INF}+\beta_{6} \mathrm{PDB}+\beta_{7} \mathrm{BIR}+\beta_{8} \mathrm{NTR}+\beta_{9} \mathrm{ROA}$

$$
+\varepsilon_{2}
$$

Keterangan:

$\mathrm{Y}_{1}=$ Return on Asset (ROA)

$Y_{2}=$ Return Saham

$\beta_{1}, \beta_{2}, \beta_{3}, \beta_{4}=$ slope pada persamaan struktural 1

$\beta_{5}, \beta_{6}, \beta_{7}, \beta_{8}, \beta_{9}=$ slope pada persamaan struktural 2

INF = Inflasi

$\mathrm{PDB}=$ Produk Domestik Bruto

$\mathrm{BIR}=\mathrm{B} \mid$ Rate

NTR = Nilai Tukar Rupiah

$\varepsilon_{1}=$ Variabel lain yang mempengaruhi $Y_{1}$

$\varepsilon_{2}=$ Variabel lain yang mempengaruhi $Y_{2}$

\section{METODE PENELITIAN}

Pendekatan Penelitian

Pendekatan yang digunakan dalam penelitian ini adalah pendekatan kuantitatif. Hal tersebut sesuai dengan penelitian ini karena indikator dari setiap variabel yang digunakan dalam bentuk numerik yang selanjutnya akan dianalisis dengan metode statistik yang tepat.

\section{Identifikasi Variabel}

Variabel eksogen yang digunakan dalam penelitian ini adalah inflasi, Produk Domestik Bruto (PDB), BI rate, dan nilai tukar rupiah, sedangkan variabel endogen adalah return saham dan variabel intervening adalah profitabilitas yang diukur oleh Return on Asset (ROA).

\section{Definisi Operasional Variabel}

1. Return saham merupakan imbal hasil yang diperoleh oleh para pemegang saham sebagai hasil dari investasi yang dilakukan perusahaan. Menurut Ross, et al. (2003:238), return saham dapat dihitung menggunakan rumus sebagai berikut:

$\mathrm{R}_{\mathrm{it}}=\frac{\mathrm{P}_{\mathrm{t}}-\mathrm{P}_{\mathrm{t}-1}}{\mathrm{P}_{\mathrm{t}-1}} \times 100 \%$

Keterangan:

$\mathrm{R}_{\mathrm{it}}=$ Return saham

$P_{\dagger}=$ Harga saham periode sekarang

$\mathrm{P}_{\mathrm{t}-1}=$ Harga saham periode sebelumnya

Data harga saham yang digunakan dalam penelitian ini adalah harga saham PT. Bank Panin Dubai Syariah, Tbk saat closing price setiap akhir bulan mulai Januari 2014 sampai Juni 2017. Data pergerakan harga saham diperoleh dari website www.finance.yahoo.com. Selanjutnya, data harga saham diolah sehingga menghasilkan data return 
Nidya, et al/Jurnal Ekonomi Syariah Teori dan Terapan Vol. 5 No. 10 Oktober 2018: 873-888; ANALISIS JALUR FAKTOR MAKROEKONOMI TERHADAP RETURN SAHAM SYARIAH

saham. Jenis data dalam bentuk bulanan selama periode Februari 2014 sampai Juni 2017.

2. Return on Asset (ROA). Menurut Surat Edaran BI Nomor 3/30/DPNP tanggal 14 Desember 2001, perhitungan rasio ROA dapat digunakan dengan menggunakan rumus berikut ini:

ROA $=\frac{\text { Laba sebelum Pajak }}{\text { Total Asset }} \times 100 \%$

Data rasio ROA diperoleh dari perhitungan menggunakan persamaan di atas berdasarkan Laporan Kevangan Publikasi PT. Bank Panin Dubai Syariah, Tbk pada Bank Indonesia melalui website www.bi.go.id. Jenis data dalam bentuk bulanan selama periode Februari 2014 sampai Juni 2017.

3. Inflasi. Data laju inflasi dalam penelitian ini diperoleh dari Bank Indonesia melalui website www.bi.go.id_berdasarkan Indeks Harga Konsumen (IHK). Jenis data dalam bentuk bulanan selama periode Februari 2014 sampai dengan Juni 2017.

4. Produk Domestik Bruto (PDB). PDB dalam penelitian ini diproksikan oleh Indeks Produksi Industri (IPI). IPI dipilih sebagai representasi dari PDB karena tidak tersedianya data PDB bulanan. Data yang digunakan adalah Indeks Produksi Bulanan Industri Besar dan Sedang yang diperoleh dari Badan Pusat Statistik (BPS) melalui website www.bps.go.id. Data yang disajikan dalam bentuk bulanan selama periode Februari 2014 sampai dengan Juni 2017.

5. Bl rate. Data BI rate dan BI 7-Day Repo Rate yang digunakan dalam penelitian ini diperoleh dari Bank Indonesia melalui website www.bi.go.id. Jenis data dalam bentuk bulanan, dimana data $\mathrm{Bl}$ rate digunakan pada periode Februari 2014 sampai Juli 2016 dan BI 7-Day Repo Rate digunakan pada periode Agustus 2016 sampai Juni 2017.

6. Nilai tukar rupiah. Data nilai tukar rupiah diperoleh dari Bank Indonesia melalui website www.bi.go.id. Jenis data dalam bentuk bulanan selama periode Februari 2014 sampai Juni 2017.

\section{Teknik Analisis Data}

Teknik analisis data yang digunakan adalah path analysis dengan tujuan melihat pengaruh antara inflasi, PDB, BI rate, dan nilai tukar rupiah terhadap ROA serta melihat pengaruh antara inflasi, PDB, $\mathrm{BI}$ rate, nilai tukar rupiah, dan ROA terhadap return saham.

\section{HASIL DAN PEMBAHASAN}

\section{Uji Normalitas}

Uji normalitas bertujuan untuk menguji apakah dalam model regresi, data residual memiliki distribusi normal (Ghozali, 2016:154).
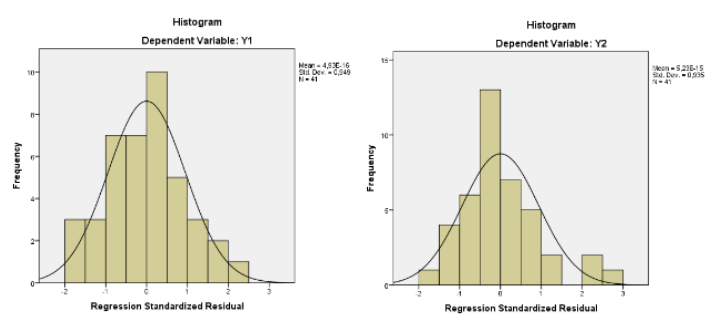

Sumber: Hasil Uji IBM SPSS 20 (data diolah)

\section{Gambar 1.}

Uji Normalitas

Berdasarkan gambar di atas, model regresi dalam penelitian ini telah memenuhi asumsi normalitas.

\section{Uji Heteroskedastisitas}


Nidya, et al/Jurnal Ekonomi Syariah Teori dan Terapan Vol. 5 No. 10 Oktober 2018: 873-888; ANALISIS JALUR FAKTOR MAKROEKONOMI TERHADAP RETURN SAHAM SYARIAH

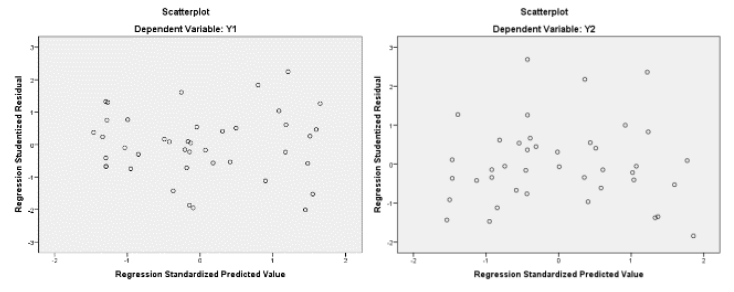

Sumber: Hasil Uji IBM SPSS 20 (data diolah)

Gambar 2.

Uji Heteroskedastisitas

Berdasarkan gambar di atas, maka kedua persamaan telah memenuhi asumsi heteroskedastisitas.

Uji Multikolinearitas

Tabel 1.

Uji Multikolinearitas

\begin{tabular}{|l|c|c|}
\hline \multicolumn{1}{|c|}{ Variabel } & VIF & Tolerance \\
\hline \multicolumn{2}{|l|}{ Return on Asset (ROA) } \\
\hline Inflasi & 2,045 & 0,489 \\
\hline IPI & 4,760 & 0,210 \\
\hline BI rate & 3,010 & 0,332 \\
\hline $\begin{array}{l}\text { Nilai Tukar } \\
\text { Rupiah }\end{array}$ & 2,247 & 0,445 \\
\hline \multicolumn{2}{|l|}{ Return Saham } \\
\hline \begin{tabular}{l} 
Inflasi \\
\hline IPI
\end{tabular} BI rate & 3,760 & 0,489 \\
\hline $\begin{array}{l}\text { Nilai Tukar } \\
\text { Rupiah }\end{array}$ & 2,731 & 0,210 \\
\hline $\begin{array}{l}\text { Return on } \\
\text { Asset (ROA) }\end{array}$ & 2,193 & 0,366 \\
\hline
\end{tabular}

Sumber: Hasil Uji IBM SPSS 20 (data diolah)

Nilai VIF dari kedua persamaan dalam penelitian ini memiliki nilai VIF kurang dari 10 dan nilai tolerance lebih dari 0,1 sehingga kedua persamaan tidak terjadi multikolinearitas.

\section{Uji Autokorelasi}

Uji autokorelasi bertujuan untuk mengetahui ada tidaknya hubungan antara error residual.

Tabel 2.

Uji Autokorelasi

\begin{tabular}{|l|l|l|}
\hline $\begin{array}{l}\text { Variabel } \\
\text { Endogen }\end{array}$ & $\begin{array}{c}\text { Durbin- } \\
\text { Watson }\end{array}$ & Hasil \\
\hline
\end{tabular}

\begin{tabular}{|l|l|l|}
\hline ROA & 1,670 & $-2<1,670<2$ \\
\hline $\begin{array}{l}\text { Return } \\
\text { Saham }\end{array}$ & 1,251 & $-2<1,251<2$ \\
\hline
\end{tabular}

Sumber: Hasil Uji IBM SPSS 20 (data diolah)

Nilai DW berada antara -2 sampai 2 sehingga tidak ada autokorelasi pada model regresi.

\section{Analisis Jalur}

Tabel 3.

Hasil R2 dan Adjusted $\mathrm{R}^{2}$

\begin{tabular}{|l|c|c|}
\hline $\begin{array}{c}\text { Variabel } \\
\text { Endogen }\end{array}$ & $\mathbf{R}^{\mathbf{2}}$ & ${\text { Adj } \mathbf{R}^{\mathbf{2}}}$ \\
\hline ROA & 0,544 & 0,493 \\
\hline $\begin{array}{l}\text { Return } \\
\text { Saham }\end{array}$ & 0,327 & 0,231 \\
\hline
\end{tabular}

Sumber: Hasil Uji IBM SPSS 20 (data diolah)

Berdasarkan tabel di atas, besarnya koefisien determinasi persamaan pertama untuk variabel endogen ROA adalah sebesar 0,544 atau 54,4\%, artinya, variabel-variabel eksogen inflasi, PDB, BI rate, dan nilai tukar rupiah mampu menjelaskan variabel endogen ROA sebesar $54,4 \%$ dan sisanya $45,6 \%$ dijelaskan oleh variabel lain diluar penelitian. Koefisien determinasi pada persamaan kedua untuk variabel endogen return saham adalah sebesar 0,327 atau $32,7 \%$, artinya, inflasi, PDB, BI rate, nilai tukar rupiah, dan ROA mampu menjelaskan variabel endogen return saham sebesar $32,7 \%$ dan sisanya $67,3 \%$ dijelaskan oleh variabel lain diluar penelitian.

Hasil regresi dari kedua persamaan dalam penelitian ini adalah:

$$
\begin{aligned}
Y_{1}= & -0,044 \mathrm{INF}-0,002 \mathrm{PDB}+0,468 \mathrm{BIR}- \\
& 0,470 \mathrm{NTR}+0,675 \\
Y_{2}= & 0,314 \mathrm{INF}+0,578 \mathrm{PDB}+0,333 \mathrm{BIR}- \\
& 0,594 \mathrm{NTR}+0,044 \mathrm{ROA}+0,820
\end{aligned}
$$


Nidya, et al/Jurnal Ekonomi Syariah Teori dan Terapan Vol. 5 No. 10 Oktober 2018: 873-888; ANALISIS JALUR FAKTOR MAKROEKONOMI TERHADAP RETURN SAHAM SYARIAH

Hasil uji signifikan parsial antar variabel dapat dijelaskan pada tabel berikut ini:

Tabel 4.

Uji Signifikan Parsial

\begin{tabular}{|l|c|c|}
\hline \multicolumn{1}{|c|}{ Variabel } & t-hitung & Sig. \\
\hline Return on Asset (ROA) & \\
\hline Inflasi & $-0,273$ & 0,786 \\
\hline IPI & $-0,007$ & 0,994 \\
\hline BI rate & 2,395 & 0,022 \\
\hline $\begin{array}{l}\text { Nilai Tukar } \\
\text { Rupiah }\end{array}$ & $-2,785$ & 0,008 \\
\hline Return Saham \\
\hline Inflasi & 1,582 & 0,123 \\
\hline IPI & 1,910 & 0,064 \\
\hline BI rate & 1,286 & 0,207 \\
\hline $\begin{array}{l}\text { Nilai Tukar } \\
\text { Rupiah }\end{array}$ & $-2,593$ & 0,014 \\
\hline $\begin{array}{l}\text { Return on } \\
\text { Asset (ROA) }\end{array}$ & 0,213 & 0,832 \\
\hline
\end{tabular}

Sumber: Hasil Uji IBM SPSS 20 (data diolah)

\section{Pembahasan}

\section{Pengaruh Inflasi terhadap Profitabilitas}

Hasil penelitian menunjukkan bahwa inflasi berpengaruh negatif tidak signifikan terhadap ROA pada PT. Bank Panin Dubai Syariah, Tbk periode 2014-2017. Hal tersebut ditunjukkan oleh nilai signifikansi yang berada di atas level of significance $5 \%$ yaitu 0,786 . Hal ini sesuai dengan penelitian yang dilakukan oleh Stiawan (2009), Syachfuddin (2017) dan Wibowo dan Muhammad (2013) yang menyatakan bahwa inflasi memiliki arah negatif tidak signifikan terhadap ROA.

Kenaikan harga barang-barang dan jasa menimbulkan nilai peredaran vang di masyarakat mengalami penurunan. Kondisi tersebut tidak serta merta mempengaruhi keputusan masyarakat dalam berinvestasi dan menyimpan dana di bank syariah. Rosanna (2007:55) menyebutkan bahwa pada saat inflasi yang tinggi maka masyarakat akan lebih menaruh perhatian dan kepercayaannya pada perbankan syariah dibandingkan perbankan konvensional sehingga bank syariah akan tetap memperoleh keuntungan.

Hal ini juga didukung oleh pendapat Wibowo dan Muhammad (2013) yang menyatakan bahwa inflasi tidak banyak mengurangi deposito maupun tabungan pada bank syariah. Hal ini mengisyaratkan bahwa ada sedikit daya tahan bank syariah terhadap terjadinya inflasi dalam suatu negara.

\section{Pengaruh Produk Domestik Bruto (PDB) terhadap Profitabilitas}

Hasil penelitian menunjukkan bahwa IPI sebagai representasi dari PDB berpengaruh negatif tidak signifikan terhadap ROA pada PT. Bank Panin Dubai Syariah, Tbk periode 2014-2017. Hal tersebut ditunjukkan oleh nilai signifikan yang berada di atas level of significance $5 \%$ yaitu 0,994 . Hasil penelitian ini sesuai dengan penelitian yang dilakukan oleh Stiawan (2009) dan Syachfuddin (2017) yang menyatakan bahwa PDB berpengaruh negatif tidak signifikan terhadap ROA bank syariah.

Dalam penelitian ini, PDB tidak berpengaruh secara langsung pada pencapaian profitabilitas bank syariah. Tidak berpengaruhnya PDB terhadap ROA pada PT. Bank Panin Dubai Syariah, Tbk terjadi karena PDB merupakan faktor makroekonomi yang sulit diprediksi atau dikendalikan oleh dunia perbankan dimana PDB merupakan suatu ukuran 
Nidya, et al/Jurnal Ekonomi Syariah Teori dan Terapan Vol. 5 No. 10 Oktober 2018: 873-888; ANALISIS JALUR FAKTOR MAKROEKONOMI TERHADAP RETURN SAHAM SYARIAH

kesejahteraan

yang

hanya

mengindikasikan perubahan pendapatan dan pengeluaran masyarakat dalam suatu negara. Menurut Syachfuddin (2017), PDB tidak bisa mempengaruhi kegiatan operasional bank secara langsung seperti aktivitas penyaluran pembiayaan yang diberikan bank kepada nasabah. Kegiatan operasional lembaga perbankan masih tergantung pada kebijakan dan strategi yang telah ditetapkan sehubungan dengan aktivitas perbankan dalam menyalurkan pembiayaan kepada masyarakat.

Hasil penelitian ini juga sesuai dengan penelitian yang dilakukan oleh Yanuardi, dkk (2014) yang menyimpulkan bahwa lembaga perbankan mampu mengatasi dan menyesuaikan diri dengan perubahan PDB yang terjadi di Indonesia. Hal ini mengindikasikan bahwa perusahaan lebih memperhatikan dalam pembuatan kebijakan dan strategi perusahaan dalam upaya mencapai dan meningkatkan profitabilitasnya.

\section{Pengaruh BI Rate terhadap Profitabilitas}

Hasil penelitian menunjukkan bahwa BI rate berpengaruh positif signifikan terhadap ROA pada PT. Bank Panin Dubai Syariah, Tbk periode 2014-2017. Hal ini ditunjukkan oleh nilai signifikansi yang berada di bawah level of significance $5 \%$ yaitu 0,022 dan nilai t-hitung yang lebih besar dari nilai t-tabel 1,685 sebesar 2,395 dengan koefisien sebesar 0,468, artinya setiap terjadi kenaikan pada BI rate maka akan menaikkan ROA pada PT. Bank Panin Dubai Syariah, Tbk. Hal ini sesuai dengan penelitian yang dilakukan oleh Kurniasih (2012) yang menyatakan bahwa suku bunga $\mathrm{Bl}$ rate berpengaruh positif signifikan terhadap ROA bank syariah.

Irawan (2010) menyimpulkan bahwa tingkat pengembalian dari bank syariah memiliki hubungan erat dengan suku bunga bank konvensional. Dengan mempertimbangkan adanya kebebasan nasabah dalam menentukan dimana dia akan menempatkan, maka perbedaan rate of return dari kedua sistem perbankan akan menetukan kemana dana itu mengalir.

Mengacu pada hasil penelitian, Sukmana (2010) menjelaskan tentang strategi yang diterapkan oleh bank syariah dalam menghadapi perubahan tingkat suku bunga, yaitu mengembangkan pasar vang syariah guna mendapatkan sumber pendanaan. Berdasarkan laporan tahunan 2014 perusahaan, seiring dengan kenaikan BI rate, PT. Bank Panin Dubai Syariah, Tbk lebih terfokus dalam mengelola likuiditas yang efisien dengan menempatkan idle funds pada instrumen yang lebih pendek jangka waktunya. Hubungan yang positif signifikan antara $\mathrm{BI}$ rate dengan profitabilitas perusahaan terjadi karena perusahaan mendapatkan keuntungan dari penempatan dana yang dilakukan pada instrumen-instrumen keuangan syariah.

\section{Pengaruh Nilai Tukar Rupiah terhadap Profitabilitas \\ Hasil penelitian menunjukkan bahwa nilai tukar rupiah berpengaruh negatif signifikan terhadap ROA pada PT. Bank}


Nidya, et al/Jurnal Ekonomi Syariah Teori dan Terapan Vol. 5 No. 10 Oktober 2018: 873-888; ANALISIS JALUR FAKTOR MAKROEKONOMI TERHADAP RETURN SAHAM SYARIAH

Panin Dubai Syariah, Tbk periode 20142017. Hal ini ditunjukkan oleh nilai signifikansi yang berada di bawah level of significance $5 \%$ yaitu 0,008 dan nilai $t$ hitung lebih besar dari nilai t-tabel 1,685 sebesar 2,785 dengan koefisien sebesar 0,470 . Ketika nilai tukar rupiah mengalami depresiasi maka profitabilitas akan meningkat. Hal ini sesuai dengan hasil penelitian yang dilakukan oleh Gufron (2015) yang menyatakan bahwa nilai tukar berpengaruh negatif signifikan terhadap ROA.

Dalam perdagangan valuta asing, bank syariah akan mendapatkan keuntungan melalui fee dan selisih kurs nilai tukar dari adanya fluktuasi nilai tukar rupiah yang terjadi. Hal tersebut akan turut berdampak pada profitabilitas bank syariah. PT. Bank Panin Dubai Syariah, Tbk merupakan salah satu Bank Umum Swasta Nasional (BUSN) Devisa yang melakukan kegiatan usaha dalam valuta asing sehingga pencapaian keuntungan perusahaan akan dipengaruhi oleh nilai tukar rupiah. Pendapat ini didukung oleh pernyataan Arifin (2006:231) yang menyatakan bahwa "apabila terjadi depresiasi rupiah terhadap dollar AS, maka akan berdampak pada profitabilitas bank".

\section{Pengaruh Inflasi terhadap Return Saham}

Hasil penelitian menunjukkan bahwa inflasi berpengaruh positif tidak signifikan terhadap return saham pada PT. Bank Panin Dubai Syariah, Tbk periode 20142017. Hal ini ditunjukkan oleh nilai signifikan yang berada di atas level of signficance $5 \%$ yaitu 0,123 . Hasil penelitian ini sesuai dengan penelitian yang dilakukan oleh Koostanto (2013) yang menyatakan bahwa inflasi berpengaruh positif tidak signifikan dalam memprediksi return saham.

Selama periode pengamatan, diperoleh rata-rata tingkat inflasi di Indonesia adalah sebesar 5,1602\% yang berarti inflasi masih berada dibawah $10 \%$. Inflasi yang rendah tidak membuat banyak pengaruh terhadap minat seorang investor untuk berinvestasi sehingga investor memberikan reaksi positif dibuktikan melalui kemampuannya untuk tetap melakukan investasi di pasar modal, khususnya saham. Menurut Kewal (2012), jika inflasi menembus $10 \%$ maka pasar modal akan terganggu yang menyebabkan Bank Indonesia akan mengeluarkan kebijakan dengan meningkatkan $\mathrm{Bl}$ rate yang mengakibatkan investor cenderung mengalihkan modalnya di sektor perbankan. Hal ini mendukung hasil penelitian yang menyatakan bahwa inflasi berpengaruh positif tidak signifikan terhadap return saham.

\section{Pengaruh Produk Domestik Bruto (PDB) terhadap Return Saham}

Hasil penelitian menunjukkan bahwa IPI sebagai representasi dari PDB berpengaruh positif tidak signifikan terhadap return saham pada PT. Bank Panin Dubai Syariah, Tbk periode 20142017. Hal ini ditunjukkan oleh nilai signifikan yang berada di atas level of significance 
Nidya, et al/Jurnal Ekonomi Syariah Teori dan Terapan Vol. 5 No. 10 Oktober 2018: 873-888; ANALISIS JALUR FAKTOR MAKROEKONOMI TERHADAP RETURN SAHAM SYARIAH

$5 \%$ yaitu 0,064 . Hasil penelitian ini sesuai dengan hasil penelitian yang dilakukan oleh Mayfi dan Rudianto (2014) yang menyimpulkan bahwa PDB berpengaruh positif tidak signifikan terhadap return saham.

Menurut Mayfi dan Rudianto (2014), peningkatan PDB suatu negara hanya berpengaruh secara langsung pada konsumsi produk pada suatu perusahaan sehingga hal tersebut tidak dapat mempengaruhi peningkatan harga saham secara langsung. Pendapat ini mendukung hasil penelitian ini yang menyatakan bahwa PDB berpengaruh positif tidak signifikan terhadap return saham pada PT. Bank Panin Dubai Syariah, Tbk.

\section{Pengaruh BI Rate terhadap Return Saham}

Hasil penelitian menunjukkan bahwa $\mathrm{BI}$ rate berpengaruh positif tidak signifikan terhadap return saham pada PT. Bank Panin Dubai Syariah, Tbk periode 20142017. Hal ini ditunjukkan oleh nilai signifikan yang berada di atas level of significance $5 \%$ yaitu 0,207 . Hal ini didukung oleh hasil penelitian yang dilakukan oleh Titman dan Warga (1989).

Mengacu pada hasil penelitian, seorang investor tidak memperhatikan perubahan $\mathrm{BI}$ rate dalam menentukan keputusan investasinya pada suatu saham syariah di pasar modal. Keputusan investor dalam melakukan aktivitas jual beli saham pada perusahaan tidak secara langsung dipengaruhi oleh perubahan BI rate yang terjadi, yang secara berkelanjutan mempengaruhi return saham perusahaan.
Seorang investor lebih cenderung memperhatikan variabel-variabel lain di luar penelitian ini dibandingkan dengan perubahan $\mathrm{Bl}$ rate yang ditetapkan oleh Bank Indonesia dalam hal pengambilan keputusan investasi pada pembelian saham yang secara berkelanjutan mempengaruhi return saham perusahaan karena dalam penelitian ini, BI rate tidak memiliki pengaruh yang signifikan terhadap return saham pada PT. Bank Panin Dubai Syariah, Tbk.

Pengaruh Nilai Tukar Rupiah terhadap Return Saham

Hasil penelitian menunjukkan bahwa nilai tukar rupiah berpengaruh negatif signifikan terhadap return saham pada PT. Bank Panin Dubai Syariah, Tbk periode 2014-2017. Hal ini ditunjukkan oleh nilai signifikan yang berada di bawah level of significance $5 \%$ yaitu 0,014 dan nilai $t$ hitung lebih besar dari nilai t-tabel 1,685 sebesar 2,593 dengan koefisien sebesar 0,594, artinya ketika nilai tukar rupiah mengalami depresiasi maka return saham pada PT. Bank Panin Dubai Syariah, Tbk mengalami peningkatan. Hal ini didukung oleh penelitian yang dilakukan oleh Prihantini (2009) dan Pujawati, dkk (2015) yang menyatakan bahwa nilai tukar rupiah berpengaruh negatif signifikan terhadap return saham.

Menurut Pujawati, dkk (2015), nilai tukar rupiah berpengaruh negatif signifikan terhadap return saham mendukung teori yang menyatakan bahwa depresiasi nilai mata vang rupiah terhadap dollar akan memberikan pengaruh yang 
Nidya, et al/Jurnal Ekonomi Syariah Teori dan Terapan Vol. 5 No. 10 Oktober 2018: 873-888; ANALISIS JALUR FAKTOR MAKROEKONOMI TERHADAP RETURN SAHAM SYARIAH

menguntungkan bagi perusahaan.

Perubahan nilai tukar rupiah terhadap dollar AS turut mempengaruhi penerimaan bank syariah dalam bentuk rupiah. Ketika nilai mata uang rupiah mengalami penurunan (depresiasi), maka hal ini akan menyebabkan return saham mengalami peningkatan.

Tujuan seorang investor menanamkan modalnya dalam bentuk investasi saham adalah untuk memperoleh return yang besar. Mengacu pada hasil penelitian, seorang investor lebih mempertimbangkan nilai tukar rupiah sebagai bahan pertimbangan dalam hal pengambilan keputusan investasi. Perubahan nilai tukar mata uang sangat berperan dalam penentuan return saham bagi perusahaan.

\section{Pengaruh Profitabilitas terhadap Return Saham}

Hasil penelitian menunjukkan bahwa ROA berpengaruh positif tidak signifikan terhadap return saham pada PT. Bank Panin Dubai Syariah, Tbk periode 20142017. Hal ini ditunjukkan oleh nilai signifikan yang berada di atas level of significance $5 \%$ yaitu 0,832 . Hasil penelitian ini didukung oleh penelitian yang dilakukan oleh Syahputri (2015) dan Aryanti, dkk (2016) yang menyatakan bahwa ROA berpengaruh positif tidak signifikan terhadap return saham syariah.

Profitabilitas dapat dijadikan sebagai ukuran kinerja perusahaan dalam menghasilkan keuntungan. Perolehan profitabilitas yang tinggi akan turut mempengaruhi harga saham yang ditawarkan sekaligus return sahamnya. Namun, dalam penelitian ini, seorang investor tidak terlalu mempertimbangkan ROA pada PT. Bank Panin Dubai Syariah, Tbk dalam hal keputusan investasi yang turut mempengaruhi besarnya return yang investor dapatkan di kemudian hari. Faktor-faktor yang mempengaruhi return saham tidak hanya berasal dari ROA perusahaan, tetapi banyak variabelvariabel lain yang mempengaruhi return saham diluar variabel-variabel yang digunakan dalam penelitian.

\section{SIMPULAN}

Berdasarkan hasil analisis dan uji hipotesis dalam penelitian ini, kesimpulan yang diperoleh adalah sebagai berikut:

1. Inflasi berpengaruh negatif tidak signifikan dengan besarnya koefisien pengaruh langsung 0,044 terhadap Return on Asset (ROA) pada PT. Bank Panin Dubai Syariah, Tbk periode 2014-2017.

2. Produk Domestik Bruto (PDB) yang diproksikan oleh Indeks Produksi Industri (IPI) berpengaruh negatif tidak signifikan dengan besarnya koefisien pengaruh langsung 0,002 terhadap Return on Asset (ROA) pada PT. Bank Panin Dubai Syariah, Tbk periode 2014-2017.

3. BI rate berpengaruh positif signifikan dengan besarnya koefisien pengaruh langsung 0,468 terhadap Return on Asset (ROA) pada PT. Bank Panin Dubai Syariah, Tbk periode 2014-2017.

4. Nilai tukar rupiah berpengaruh negatif signifikan dengan besarnya koefisien pengaruh langsung 0,470 terhadap Return 
Nidya, et al/Jurnal Ekonomi Syariah Teori dan Terapan Vol. 5 No. 10 Oktober 2018: 873-888; ANALISIS JALUR FAKTOR MAKROEKONOMI TERHADAP RETURN SAHAM SYARIAH

on Asset (ROA) pada PT. Bank Panin Dubai Syariah, Tbk periode 2014-2017.

5. Inflasi berpengaruh positif tidak signifikan dengan besarnya koefisien pengaruh langsung 0,314 dan pengaruh tidak langsungnya 0,002 terhadap return saham pada PT. Bank Panin Dubai Syariah, Tbk periode 2014-2017.

6. Produk Domestik Bruto (PDB) yang diproksikan oleh Indeks Produksi Industri (IPI) berpengaruh positif tidak signifikan dengan besarnya koefisien pengaruh langsung 0,578 dan pengaruh tidak langsung 0,0 terhadap return saham pada PT. Bank Panin Dubai Syariah, Tbk periode 2014-2017.

7. Bl rate berpengaruh positif tidak signifikan dengan besarnya koefisien pengaruh langsung 0,333 dan pengaruh tidak langsung 0,02 terhadap return saham pada PT. Bank Panin Dubai Syariah, Tbk periode 2014-2017.

8. Nilai tukar rupiah berpengaruh negatif signifikan dengan besarnya koefisien pengaruh langsung 0,594 dan pengaruh tidak langsung 0,02 terhadap return saham pada PT. Bank Panin Dubai Syariah, Tbk periode 2014-2017.

9. Return on Asset (ROA) berpengaruh positif tidak signifikan dengan besarnya koefisien pengaruh langsung 0,044 terhadap return saham pada PT. Bank Panin Dubai Syariah, Tbk periode 20142017.

\section{DAFTAR PUSTAKA}

Arifin, Zainul. 2006. Dasar-dasar Manajemen Bank Syariah. Jakarta: Pustaka Alvabet.
Aryanti, dkk. 2016. Pengaruh ROA, ROE, NPM, dan CR terhadap Return Saham pada Perusahaan yang Terdaftar di Jakarta Islamic Index (JII). I-Finance, Vol.2 No.2, hal. 54-71.

Darmadji, Tjiptono \& Fakhrudin, Henry M. 2006. Pasar Modal di Indonesia Pendekatan Tanya Jawab. Jakarta: Salemba Empat.

Dendawijaya, Lukman. 2009. Manajemen Perbankan, Edisi Kedua. Jakarta: Ghalia Indonesia.

Fatmawati, Nur Lailatul. 2017. Pengaruh BI Rate dan Tingkat Kesehtaan Bank terhadap Tingkat Bagi Hasil Pembiayaan Mudharabah di Bank Syariah Mandiri Periode 2008-2015. (Online), (http://digilib.uin-suka.ac.id, diakses pada 8 Januari 2018).

Ghozali, Imam. 2016. Aplikasi Analisis Multivariate dengan Program IBM SPSS 23, Edisi 8. Semarang: Badan Penerbit Universitas Diponegoro.

Greenwald, Douglas. 1982. Encyclopedia of Economics. New York: McGraw-Hill, Inc.

Gufron, Muzaki. 2015. Pengaruh Inflasi, Suku Bunga dan Nilai Tukar terhadap Profitabilitas Bank Umum Syariah di Indoensia (Periode Januari 2010-April 2015). Skripsi tidak diterbitkan. Surabaya: Fakultas Ekonomi dan Bisnis Universitas Airlangga.

Irawan, Toni. 26 Agustus 2010. Sistem Perbankan Ganda: Pengalaman Malaysia. Iqtishodia jurnal ekonomi islam republika, hlm. 7. 
Nidya, et al/Jurnal Ekonomi Syariah Teori dan Terapan Vol. 5 No. 10 Oktober 2018: 873-888; ANALISIS JALUR FAKTOR MAKROEKONOMI TERHADAP RETURN SAHAM SYARIAH

Kasmir. 2016. Analisis Laporan Keuangan. Jakarta: Rajawali Pers.

Kewal, S.S. 2012. Pengaruh Inflasi, Suku Bunga, Kurs dan Pertumbuhan PDB terhadap Indeks Harga Saham Gabungan. Jurnal Economia, Vol. 8, No.1.

Koostanto, Harya Buntala. 2013. Pengaruh Inflasi, Suku Bunga, Nilai Tukar dan PDB terhadap Perubahan Tingkat Pengembalian Saham Perusahaan yang Terdaftar pada Bursa Efek Indonesia, (Online), (http://repository.ipb.ac.id, diakses 30 Oktober 2017).

Kurniasih, Erni. 2012. Pengaruh Capital Adequacy Ratio (CAR), Non Performing Financing (NPF), Financing to Deposit Ratio (FDR), Biaya Operasional Pendapatan Operasional (BOPO), Suku Bunga dan Inflasi terhadap Profitabilitas (Perbandingan Bank Umum Syariah dan Bank Umum Konvensional periode 2007-2011). Skripsi diterbitkan. Yogyakarta: Fakultas Syariah dan Hukum Universitas Islam Negeri Sunan Kalijaga.

Mayfi, Fathimah \& Dudi Rudianto. 2014. Analisis Pengaruh Faktor Internal dan Eksternal Perusahaan terhadap Return Saham. Jurnal MIX, Volume IV, No.3, hal. 348-362.

Prihantini, Ratna. 2009. Analisis Pengaruh Inflasi, Nilai Tukar, ROA, DER, dan CR terhadap Return Saham (Studi Kasus Saham Industri Real Estate and Property yang Terdaftar di Bursa Efek
Indonesia periode 2003-2006). Tesis diterbitkan. Semarang: Program Studi Magister Manajemen Universitas Diponegoro.

Pujawati, Putu Eka, dkk. 2015. Pengaruh Nilai Tukar Rupiah terhadap Return Saham dengan Profitabilitas sebagai Variabel Intervening. E-Jurnal Ekonomi dan Bisnis Universitas Udayana 4.04: 220-242.

Rosanna, Rizky Dahlia. 2007. Pengaruh Inflasi, Nilai Tukar, dan Suku Bunga SBI terhadap Profitabilitas Perbankan Syariah di Indonesia Tahun 2002-2006. Tesis diterbitkan. Yogyakarta: Universitas Islam Indonesia.

Ross, A Stephen. Westerfield et.al. 2003. Fundamentals of Corporate Finance. Sixth Edition. New York: Mc Graw-Hill.

Stiawan. Adi . 2009. Analisis Pengaruh Faktor Makroekonomi, Pangsa Pasar dan Karakteristik Bank terhadap Profitabilitas Bank Syariah (Studi pada Bank Syariah periode 2005-2008). Tesis diterbitkan. Semarang: Program Studi Magister Manajemen Universitas Diponegoro.

Sukirno, Sadono. 2006. Ekonomi Pembangunan: Proses, Masalah, dan Dasar Kebijakan. Jakarta: Kencana.

Sukmana, Raditya. 26 Agustus 2010. Determinan Pembiayaan Bank Syariah di Indonesia. Iqtishodia jurnal ekonomi islam republika, hlm. 7.

Syachfuddin, Laras Andasari. 2017. Pengaruh Inflasi, Gross Domestic Product (GDP), Dana Pihak Ketiga (DPK), dan Pangsa Pasar terhadap 
Nidya, et al/Jurnal Ekonomi Syariah Teori dan Terapan Vol. 5 No. 10 Oktober 2018: 873-888;

ANALISIS JALUR FAKTOR MAKROEKONOMI TERHADAP RETURN SAHAM SYARIAH

Return on Asset (ROA) Industri

Perbankan Syariah di Indonesia

Periode 2011-2015. Skripsi tidak

diterbitkan. Surabaya: Fakultas

Ekonomi dan Bisnis Universitas

Airlangga.

Syahputri, Rianti. 2015. Pengaruh ROA,

NPM, EPS terhadap Return Saham

pada Emiten Jakarta Islamic Index

Tahun 2010-2013. Skripsi tidak

diterbitkan. Surabaya: Fakultas

Ekonomi dan Bisnis Universitas

Airlangga.

Syarul, G. 2000. Kiat Berinvestasi. Jakarta:

Erlangga.

Tandelilin, Eduardus. 2010. Portofolio dan

Investasi Teori dan Aplikasi, Edisi

Pertama. Yogyakarta: Kanisius.

Titman, Sheridan \& Arthur Warga. 1989.

Stock Return as Predictors of Interest

Rates and Inflation. Journal of

Financial and Quantitative Analysis:

Accounting and Tax, Vol.24, No.1, Maret 1989, hal.47-58.

Wibowo, Edhi Satriyo \& Muhammad

Syaichu. 2013. Analisis Pengaruh Suku

Bunga, Inflasi, CAR, BOPO, NPF terhadap Profitabilitas Bank Syariah.

Diponegoro Journal of Management,

Vol.2, No.2, hal. 1-10.

Yanuardi, Aliandra, dkk. 2014. Faktor Determinan atas Profitabilitas Perbankan yang Terdaftar di Bursa Efek Indonesia. Jurnal Akuntansi Multiparadigma, Vol.2, No.2, Agustus $2014 ; 170-344$. 